\title{
Activation of Hepatic Stellate Cells by TGFa and Collagen Type I Is Mediated by Oxidative Stress Through c-myb Expression
}

\author{
Kwan S. Lee, Martina Buck, Karl Houglum, and Mario Chojkier \\ Department of Medicine, Veterans Affairs Medical Center, and Center for Molecular Genetics, University of California, San Diego, \\ California 92161
}

\begin{abstract}
Excessive production of collagen type $I$ is a major contributor to hepatic fibrosis. Activated (myofibroblastic), but not quiescent, hepatic stellate cells (lipocytes) have a high level of collagen type $I$ and $\alpha$-smooth muscle actin expression. Therefore, stellate cell activation is a critical step in hepatic fibrosis. Here we show that quiescent stellate cells were activated by the generation of free radicals with ascorbate/ $\mathrm{FeSO}_{4}$ and by malondialdehyde, a product of lipid peroxidation. In addition, stellate cell activation by collagen type I matrix and TGF $\alpha$ was blocked by antioxidants, such as d$\alpha$-tocopherol and butylated hydroxytoluene. Moreover, oxidative stress, TGF $\alpha$ and collagen type I markedly stimulated stellate cell entry into S-phase, NFkB activity and c-myb expression, which were prevented by antioxidants. c-myb antisense oligonucleotide blocked the activation and proliferation of stellate cells induced by TGF $\alpha$. Nuclear extracts from activated, but not from quiescent, stellate cells formed a complex with the critical promoter $E$ box of the $\alpha$-smooth muscle actin gene, which was disrupted by c-myb and NFkB65 antibodies, and competed by c-myb and NFkB cognate DNA. c-Myb expression was also stimulated in activated stellate cells in carbon tetrachloride-induced hepatic injury and fibrogenesis. This study indicates that oxidative stress plays an essential role, through the induction of c-myb and NFkB, on stellate cell activation. (J. Clin. Invest. 1995. 96:2461-2468.) Key words: c-myb expression - stellate cell gene expression • oxidative stress $\bullet$ lipid peroxidation • liver fibrogenesis
\end{abstract}

\section{Introduction}

Collagen type $\mathrm{I}$, is the most excessive extracellular matrix protein in hepatic fibrosis $(1,2)$, which is in turn a major contributor to the morbidity and mortality of patients affected by chronic liver diseases. Therefore, the regulation of type I collagen gene expression is crucial in understanding the pathogenesis of this disease (3).

Although the mechanisms responsible are unknown, the increased production of collagen $\alpha_{1}(\mathrm{I})$ in liver injury is mainly a result of an enhanced collagen gene transcription $(4,5)$. From several lines of investigation, we have obtained evidence indi-

\footnotetext{
K. S. Lee and M. Buck contributed equally to this manuscript. Address correspondence to Mario Chojkier, Department of Medicine and Center for Molecular Genetics (9111-D), University of California, San Diego, San Diego, CA 92161.

Received for publication 4 April 1995 and accepted in revised form 31 July 1995.
}

The Journal of Clinical Investigation, Inc.

Volume 96, November 1995, 2461-2468 cating that aldehyde-protein adducts, including products of lipid peroxidation, modulate collagen gene expression (6-8) and may be a link between tissue injury and fibrosis (9-11). Whether the basis of fibrogenesis in disorders associated with lipid peroxidation, such as in iron overload (12), chronic viral hepatitis (Lee et al., unpublished observations), porphyria (13), alcohol- (14), and carbon tetrachloride-induced (15) hepatic injury, is linked to this intriguing process remains to be elucidated. However, we demonstrated a temporal relationship as well as colocalization of lipid peroxidation and increased expression of collagen $\alpha_{1}(\mathrm{I})$ gene, in the liver of rats treated with carbon tetrachloride or overloaded with iron $(10,11)$. These results suggest that lipid peroxidation affects collagen $\alpha_{1}(\mathrm{I})$ transcription directly and/or through the activation of cells responsible for its synthesis.

In this context, stellate cells play a key role in the pathogenesis of hepatic fibrosis $(16,17)$. Although we $(18)$ and others $(19,20)$ reported that quiescent stellate cells produce little collagen type I, activated (myofibroblastic) stellate cells display a high level of collagen $\alpha_{1}(\mathrm{I})$ gene expression $(16,17,19)$. Therefore, stellate cell activation is a critical step in hepatic fibrogenesis. Studies with primary cultures of adult rat stellate cells have provided evidence that cell-type specific growth regulatory mechanisms exist (21), but the stellate cell-specific factors regulating stellate cell proliferation and activation have not yet been identified.

In this study, we analyzed a mechanism leading to stellate cell activation. We found that oxidative stress is a common and indispensable step, in the cascade of molecular events initiated by collagen type I matrix or TGF $\alpha$, resulting in stellate cell activation and stellate cell proliferation. Moreover, our results suggest that the activation of NFkB and the induction of c$m y b$ nuclear expression by oxidative stress, are critical for the activation of stellate cells.

\section{Methods}

Cell cultures. Stellate cells were prepared from male Sprague-Dawley (400-500 grams) by in situ perfusion and single-step density Nycodenz gradient (Accurate Chemical \& Scientific Corp., Westbury, NY), as described previously $(10,18)$. The cells were mixed with $9.5 \mathrm{ml} \mathrm{Hank's}$ containing 3 grams/liter bovine serum albumin and $8 \mathrm{ml}$ of $28.7 \%$ ( wt/vol) Nycodenz in sodium-free Hank's buffer. The gradient was generated by placing $6 \mathrm{ml}$ of the Hank's/albumin solution on top of the liver cell mixture in a 50-ml centrifugation tube. After centrifugation $\left(1,000 \mathrm{~g}, 4^{\circ} \mathrm{C}, 20 \mathrm{~min}\right)$ the cells were aspirated from above the interface, washed twice in serum-free DME regular glucose medium and subsequently cultured under an atmosphere of $5 \% \mathrm{CO}_{2}, 95 \%$ air in tissue culture dishes using DME medium containing penicillin G $100 \mathrm{U} / \mathrm{ml}$, streptomycin sulfate $100 \mu \mathrm{g} / \mathrm{ml}$ and $10 \%$ fetal calf serum. For TGF $\alpha$ induced stellate cell activation, cells were cultured on plastic in a serumfree defined media (Fibroblast basal medium with Insulin, Clonetics). Fibroblast basal medium is similar to F12 medium, but contains folinic acid, Hepes buffer with $\mathrm{NaOH}, \mathrm{MgSO}_{4}$ and adenine instead of folic acid, $\mathrm{NaHCO}_{3}, \mathrm{MgCl}_{2}$ and hypoxanthine. Cells were plated on $60-\mathrm{mm}$ 
dish coated with collagen type I, EHS matrix (Matrigel) or plastic (according to the experimental design), for the initial seeding of fatstoring cells at a density of $2-3 \times 10^{6}$. Matrigel's (Collaborative Biomedical Products) major components are laminim, collagen IV, proteoglycans, entactin and nidogen. It also contains $\operatorname{TGF} \beta$, fibroblast growth factor, and tissue plasminogen activator. Treatments were started $18 \mathrm{~h}$ after hepatic stellate cell isolation, and continued for additional $120 \mathrm{~h}$ for cells cultured on plastic (with serum), EHS or collagen I matrices, and for additional $60 \mathrm{~h}$ for cells cultured in serum-free defined media. Medium was changed every $24 \mathrm{~h}$ for all conditions. The sequences of c-myb oligonucleotide phosphorothioate were: sense (5' GCC CGG AGA CCC CGA CAC 3') and antisense ( $5^{\prime}$ GTG TCG GGG TCT CCG GGC $3^{\prime}$ ). Stellate cells were identified by their typical autofluorescence at $328 \mathrm{~nm}$ excitation wavelength, staining of lipid droplets by oil red, and immunohistochemistry with a monoclonal antibody against desmin (10).

Nuclear extract preparation. Nuclei were prepared by a modification of the procedure described previously $(22,23)$. Cells were homogenized in $1 \mathrm{ml}$ of $5 \%$ citric acid, $0.5 \% \mathrm{NP}-40,10 \mathrm{mM} \mathrm{NaF}$ and $10 \mathrm{mM} \mathrm{Na}$ pyrophosphate with a glass Dounce homogenizer with a loose fitting pestle. The homogenized cells were placed above a cushion consisting of $30 \%$ sucrose and $1 \%$ citric acid. The nuclei were precipitated by a $4,000 \mathrm{~g}$ centrifugation at $4^{\circ} \mathrm{C}$ for $30 \mathrm{~min}$ and frozen at $-70^{\circ} \mathrm{C}$. Gel retardation analysis of protein-DNA complexes were performed with an oligonucleotide of the putative DNA binding site, as described previously $(23,24)$. The sense oligonucleotide were: NFkB ( $5^{\prime}$ GGG GAC TTT CCC $3^{\prime}$ ) and $\alpha$-smooth muscle actin E box (5' GAT CAT AAG CAG CTG AAC TGC C $3^{\prime}$ ).

Animals. C57BL/6 mice (20-25 grams) each received a single intraperitoneal injection of $\mathrm{CCl}_{4}$ in mineral oil $(1: 3, \mathrm{vol} / \mathrm{vol})$ at a dose of $2 \mathrm{ml} / \mathrm{kg}$ body weight, or mineral oil only (control). After $48 \mathrm{~h}$, animals were sacrificed and liver tissues were promptly removed, fixed in $10 \%$ formaldehyde and embedded in paraffin for immunohistochemical staining (10).

Immunohistochemistry. Cells, fixed with acetone: methanol (50:50) at $-20^{\circ} \mathrm{C}$ for $20 \mathrm{~min}$, and liver tissue were immunostained as described previously $(11,23)$. Antibodies directed against c-myb, NFkB65, $\alpha$ smooth muscle actin, desmin, or proliferating cell nuclear antigen (PCNA) ${ }^{1}$ were obtained from Sigma Chemical Co. (St. Louis, MO), 5 Prime 3 Prime, and Oncogene Sciences. Fluorescent labels were visualized using a dual channel Zeiss microscope as described previously (23). A phase-contrast microscope was utilized to visualize antigens with alkaline phosphatase secondary antibodies (Vector Laboratories). Cytochromes utilized were alkaline phosphatase with fast green as counterstain, and FITC with Evans blue as counterstain (Sigma Chemical Co.). The number of PCNA( +$)$, c-myb $(+)$, or $\operatorname{NFkB}(+), \alpha$-smooth muscle actin (SMA) $(+)$ cells was expressed as a percentage of total cells. At least 1,000 cells are analyzed per each experimental point, and a minimum of two observers analyzed each immunohistochemical experiment independently as described previously (23). Negative control samples were processed in parallel under the same conditions, but with omission of the first antibody.

Statistical analysis. Results were expressed as mean of at least triplicates unless stated otherwise. Either the Student $t$ or the Fisher's exact test (two-tailed) was used to evaluate the differences of the means between groups, with a $P$ value of $<0.05$ as significant.

\section{Results}

First, we examined the role of lipid peroxidation on stellate cell activation. Stellate cell activation was induced in quiescent cells growing on a EHS matrix, while inhibition of this phenotype was attempted in cells activated by collagen type I matrix (19, 20). When stellate cell activation was induced by TGF $\alpha$ (21),

1. Abbreviations used in this paper: $\mathrm{BHT}$, butylated hydroxytoluene; PCNA, proliferating cell nuclear antigen; SMA, smooth muscle actin. a defined media without serum was used. Stellate cell activation was assessed by the expression of $\alpha$-smooth muscle actin ( $\alpha$ SMA) (25), and S-phase by the presence of proliferating cell nuclear antigen (PCNA) (26).

As depicted in Fig. 1, we found that quiescent stellate cells, cultured on a EHS matrix (open bars) (control), were activated by the generation of free radicals using ascorbic acid $(200 \mu \mathrm{M}) /$ $\mathrm{FeSO}_{4}(50 \mu \mathrm{M})$ as described previously (7). Because we reported that ascorbic acid/FeSO ${ }_{4}$ induces lipid peroxidation in cultured fibroblasts, with the production of malondialdehyde and 4-hydroxynonenal (7), we tested whether malondialdehyde would mimic the effects of inducing lipid peroxidation. Indeed, malondialdehyde $(200 \mu \mathrm{M})$ markedly stimulated the activation of hepatic stellate cells (Fig. 1). Malondialdehyde at lower concentrations $(50 \mu \mathrm{M})$ was also able to activate stellate cells but to a lesser extent (data not shown). As expected, stellate cells cultured on a collagen type I matrix (closed bars) or treated with TGF $\alpha(12 \mathrm{nM})$ (hatched bars) became activated at a much higher rate than their respective control conditions (Fig. 1). The values of the control condition for TFG $\alpha$ were comparable to those of the EHS control $(<10 \%)$. Similarly, stellate cells cultured on plastic and treated with malondialdehyde displayed a more activated pattern than cells grown on plastic ( 93 vs. $58 \%$ of cells (+) for $\alpha$-SMA; $P<0.05$ ). Complementary results supporting the role of oxidative stress on stellate cell activation, included the findings that induction of stellate cell activation by a collagen type I matrix can be blocked by antioxidants, such as $\mathrm{d}-\alpha$-tocopherol $(50 \mu \mathrm{M})$ or butylated hydroxytoluene BHT (50 $\mu \mathrm{M})$ (Fig. 1). In addition, d- $\alpha$-tocopherol blocked the activation of stellate cells on plastic (14 vs $58 \%$ of cells $(+)$ for $\alpha$-SMA; $P<0.05$ ). In Fig. 2, representative examples of the association between oxidative stress and stellate cell activation, assessed by $\alpha$-SMA immunohistochemistry, are shown. The expression of $\alpha$-SMA (indicated in brown) was markedly induced in stellate cells treated with malondialdehyde (Fig. $2 \mathrm{~B}$ ) when compared to control stellate cells cultured on a EHS matrix (Fig. $2 A$ ). A similar stimulation of $\alpha$-SMA expression was observed when stellate cells were cultured on collagen type I (Fig. $2 C$ ), in agreement with previous reports $(19,20)$. Interestingly, this increased expression of $\alpha$-SMA was abolished by d- $\alpha$-tocopherol (Fig. $2 D$ ), or BHT (Fig. 1). A small percentage of the cells $(<5 \%)$ displayed mild to moderate staining when the first antibody was omitted.

Control stellate cells on a EHS matrix (Fig. 3) or control TGF $\alpha$ stellate cells were quiescent in regard to proliferation, with only $\sim 5 \%$ of the cells in S-phase. In contrast, oxidative stress induced by ascorbic acid/ $/ \mathrm{FeSO}_{4}$, collagen type I matrix, and TGF $\alpha$ markedly increased stellate cell proliferation, judging by the percentage of cells in S-phase ( $>66 \%$ for all conditions). Malondialdehyde, a product of lipid peroxidation, also stimulated stellate cell entry into S-phase. In addition, antioxidants such as $\mathrm{d}$ - $\boldsymbol{\alpha}$-tocopherol or BHT, blocked the activation of the stellate cell cycle induced by collagen type I matrix or TGF $\alpha$. Representative examples of the nuclear expression of PCNA (in brown), an index of the cell cycle S-phase (26), are shown in Fig. 4. It was negligible in control stellate cells (Fig. $4 \mathrm{~A}$ ) or when the first antibody was omitted, but it was dramatically induced in stellate cells exposed to oxidative stress (Fig. $4 B$ ).

Because NFkB plays important roles in the regulation of cell growth and function, and oxidative stress increases NFkB activity $(27,28)$, we analyzed the potential role of NFkB regulation in stellate cell activation. Stellate cell activation was asso- 


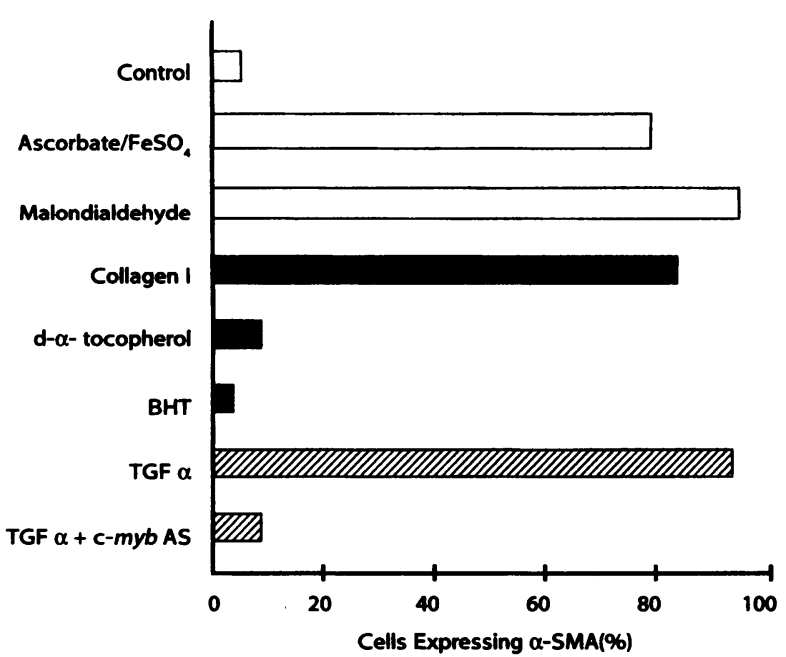

Figure 1. Oxidative stress induces the expression of $\alpha$-smooth muscle actin in hepatic stellate cells. $\alpha$-Smooth muscle actin ( $\alpha$-SMA) expression was detected by immunohistochemistry in primary stellate cells. Cells were cultured on EHS matrix (open bars) (control, ascorbic acid [200 $\mu \mathrm{M}] / \mathrm{FeSO}_{4}[50 \mu \mathrm{M}$ ] , and $200 \mu \mathrm{M}$ malondialdehyde), collagen type I matrix [closed bars] (collagen I, $50 \mu \mathrm{M} \mathrm{d}-\alpha$-tocopherol, and 50 $\mu \mathrm{M}$ butylated hydroxytoluene $[B H T]$ ), or plastic (hatched bars) (12 nM TGF $\alpha$ with and without $25 \mu \mathrm{M}$ c-myb antisense $[A S]$ ). Cells on EHS or collagen type I were cultured in media with $10 \%$ fetal calf serum, while cells on plastic were cultured on serum-free media. Values represent the percentage of cells positive for $\alpha$-SMA; $P<0.05$ for ascorbic acid/ $/ \mathrm{FeSO}_{4}$, malondialdehyde, collagen and TGF $\alpha$. The SEM was $<30 \%$ of the mean for all conditions.

ciated with the nuclear translocation and activation of $\mathrm{NFkB}$, as detected by immunofluorescence (Figs. 5 and 6 ) and gel shift analysis (Fig. 7). As shown in Fig. 5, the nuclear expression of NFkB as detected with specific antibodies against NFkB65, was

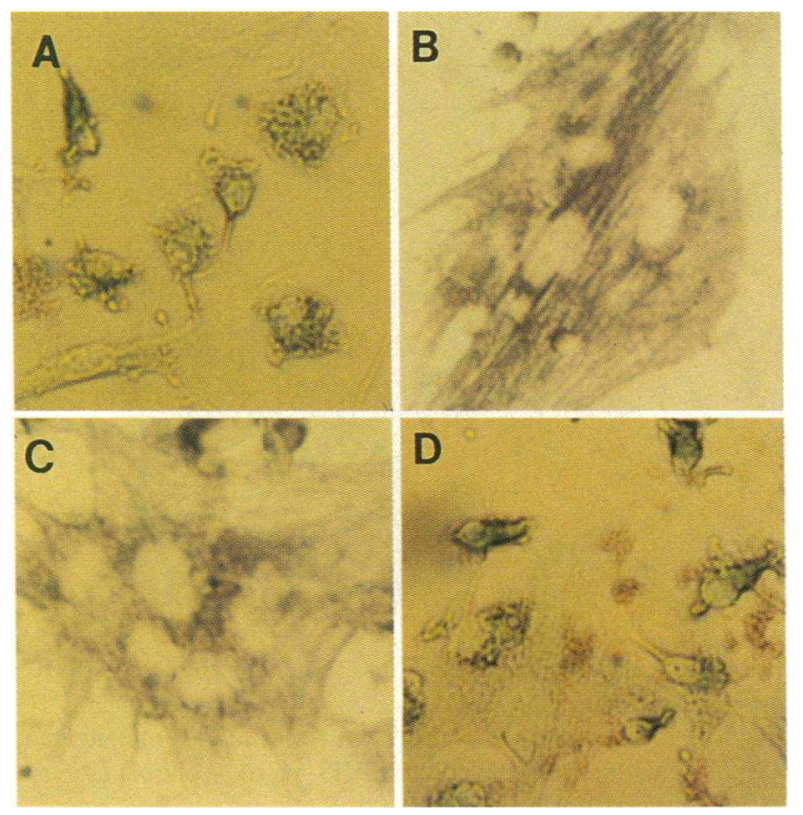

Figure 2. Representative examples of the association of $\alpha$-smooth muscle expression and oxidative stress in hepatic stellate cells. $\alpha$-SMA expression was detected using alkaline phosphatase immunohistochemistry (brown), while fast green counterstained all cells. $\alpha$ SMA immunohistochemistry is shown for control $(A), 200 \mu \mathrm{M}$ malondialdehyde $(B)$, collagen type I matrix $(C)$, and $50 \mu \mathrm{M} \mathrm{d}-\alpha$-tocopherol $(D) . \times 100$.

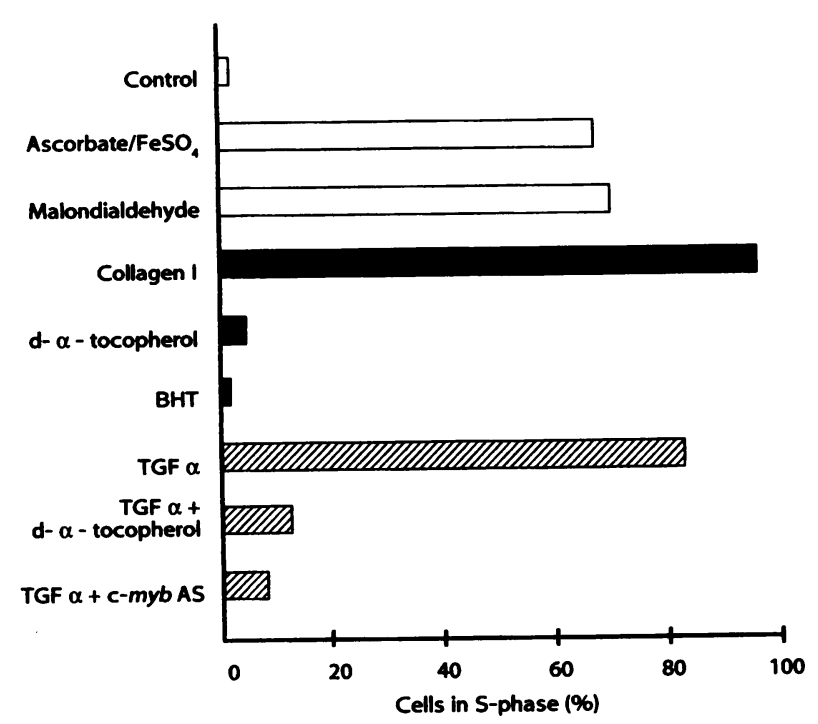

Figure 3. Oxidative stress induces hepatic stellate cell proliferation. The nuclear expression of PCNA was detected by immunohistochemistry in primary stellate cells. Cells were cultured on EHS matrix (control, ascorbic acid [200 $\mu \mathrm{M}$ ]/FeSO 4 [50 $\mu \mathrm{M}$ ], and $200 \mu \mathrm{M}$ malondialdehyde), collagen I matrix (collagen I, $50 \mu \mathrm{M}$ d- $\alpha$-tocopherol and $50 \mu \mathrm{M}$ BHT), or plastic (12 nM TGF $\alpha$ with and without $25 \mu \mathrm{M} \mathrm{c-myb}$ antisense [AS]). Cells were cultured as described in Fig. 1. Values represent the percentage of cells positive for PCNA; $P<0.05$ for ascorbic acid/ $\mathrm{FeSO}_{4}$, malondialdehyde, collagen, and TGF $\alpha$. The SEM was $<30 \%$ of the mean for all conditions.

substantially increased in stellate cells cultured on a EHS matrix and treated with malondialdehyde, or when cultured on a collagen type I matrix. The lipophilic antioxidant $\mathrm{d}-\boldsymbol{\alpha}$-tocopherol blocked the activation of NFkB induced by collagen type I, indicating that collagen type I affects NFkB activation through oxidative stress. Representative examples of $\mathrm{NFkB}$ expression are shown in Fig. 6. Quiescent stellate cells lacked nuclear NFkB (Fig. $6 A$ ), whereas stellate cells activated with malondialdehyde displayed nuclear expression of NFkB (Fig. $6 \mathrm{~B}$ ). Negligible background nuclear fluorescence was observed when the first antibody was omitted. As depicted in Fig. 7, the binding of stellate cells nuclear extracts to a NFkB cognate oligonucleotide was low in quiescent cells (Fig. 7, lane 2), but increased significantly following stellate cell activation (Fig. 7, lane 3).
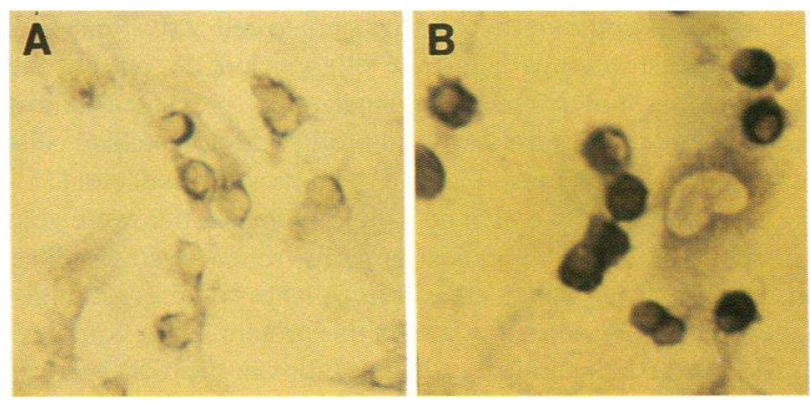

Figure 4. PCNA expression and oxidative stress are associated in hepatic stellate cells. PCNA was detected using alkaline phosphatase immunohistochemistry (brown), while fast green counterstained all cells. PCNA immunohistochemistry is shown for cells cultured on EHS matrix (control) $(A)$ and for ascorbic acid $[200 \mu \mathrm{M}] / \mathrm{FeSO}_{4}[50 \mu \mathrm{M}](\mathrm{B}) \times 100$. 


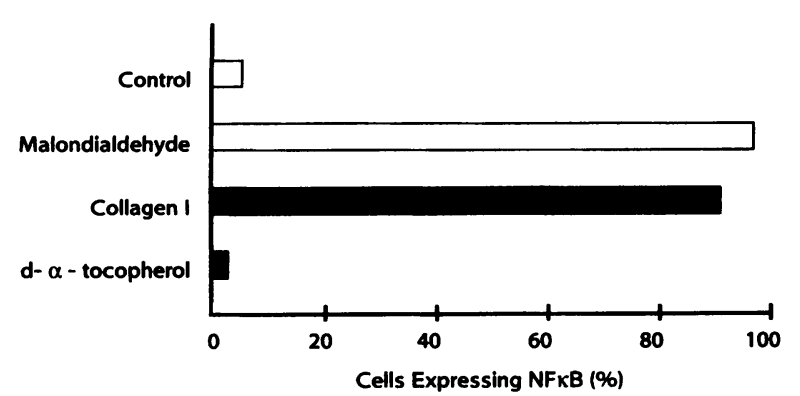

Figure 5. NFkB nuclear expression is increased in activated stellate cells. NFkB nuclear expression was detected by immunofluorescence in primary stellate cells. Cells were cultured on EHS matrix (control and $200 \mu \mathrm{M}$ malondialdehyde), or collagen type I matrix (collagen I and $50 \mu \mathrm{M} \mathrm{d}-\alpha$-tocopherol). Cells were cultured as described in Fig. 1. Values represent the percentage of cells positive for nuclear NFkB; $P$ $<0.05$ for malondialdehyde and collagen. The SEM was $<15 \%$ of the mean for all conditions.

As expected, the binding of nuclear extracts from activated stellate cells to the NFkB site was disrupted by antibodies against NFkB65 (Fig. 7, lane 4), but not by preimmune serum (not shown). In addition, the NFkB oligonucleotide abolished the complex of ${ }^{32} \mathrm{P}$-labeled NFkB oligonucleotide and nuclear extracts from activated stellate cells (Fig. 7, lane 6). In brief, antioxidants prevented stellate cell activation (Figs. 1 and 3 ), and NFkB nuclear activity (Fig. 5 and 7 ) induced by ascorbic acid $/ \mathrm{FeSO}_{4}$, collagen type I or TGF $\alpha$.

Because c-myb is an important inducer of proliferation in hematopoietic and smooth muscle cells (29-31), we tested whether c-myb expression was important for stellate cell proliferation and/or activation. First, we found that the expression of c-myb, detected by immunofluorescence using monoclonal c-myb antibodies, was enhanced in activated stellate cells, irrespective of the method of induction, and that this effect was prevented by antioxidants (Fig. 8). The nuclear expression of c-myb was increased by the generation of oxidative stress with ascorbic acid $/ \mathrm{FeSO}_{4}$, malondialdehyde, collagen type I matrix, and TGF $\alpha$. Next, we assessed whether c-myb expression affected stellate cell activation. TGF $\alpha$ induction of stellate cell activation was chosen for the c-myb antisense experiments because the control stellate cells were uniformly quiescent in defined media and in the absence of serum. Less than $5 \%$ of control cells for the TGF $\alpha$ experimental condition expressed nuclear c-myb. c- $M y b$ antisense oligonucleotide suppressed the nuclear expression of c-myb during stellate cell activation (Fig. 8). Of interest, a c-myb antisense oligonucleotide, but not the corresponding c-myb sense oligonucleotide, prevented almost completely both the activation and proliferation of stellate cells induced by TGF $\alpha$ (Figs. 1 and 3). Moreover, monoclonal cmyb antibodies and a c-myb cognate oligonucleotide were able to disrupt the binding of nuclear proteins from activated stellate cells to a NFkB oligonucleotide (Fig. 7, lanes 5 and 7), strongly suggesting the presence of $\mathrm{c}-\mathrm{myb}$ in this protein/DNA complex.

As expected, the critical promoter E box of the $\alpha$-SMA gene (32), formed complexes with nuclear extracts from activated stellate cells (Fig. 9, lane 3), but not with nuclear extracts from quiescent stellate cells (Fig. 9, lane 2). Relevant to this study, the protein-DNA complexes $(b)$ were markedly disrupted by monoclonal c-myb antibodies (Fig. 9, lane 4) and NFkB65 antibodies (Fig. 9, lane 5), and competed by oligonucleotides
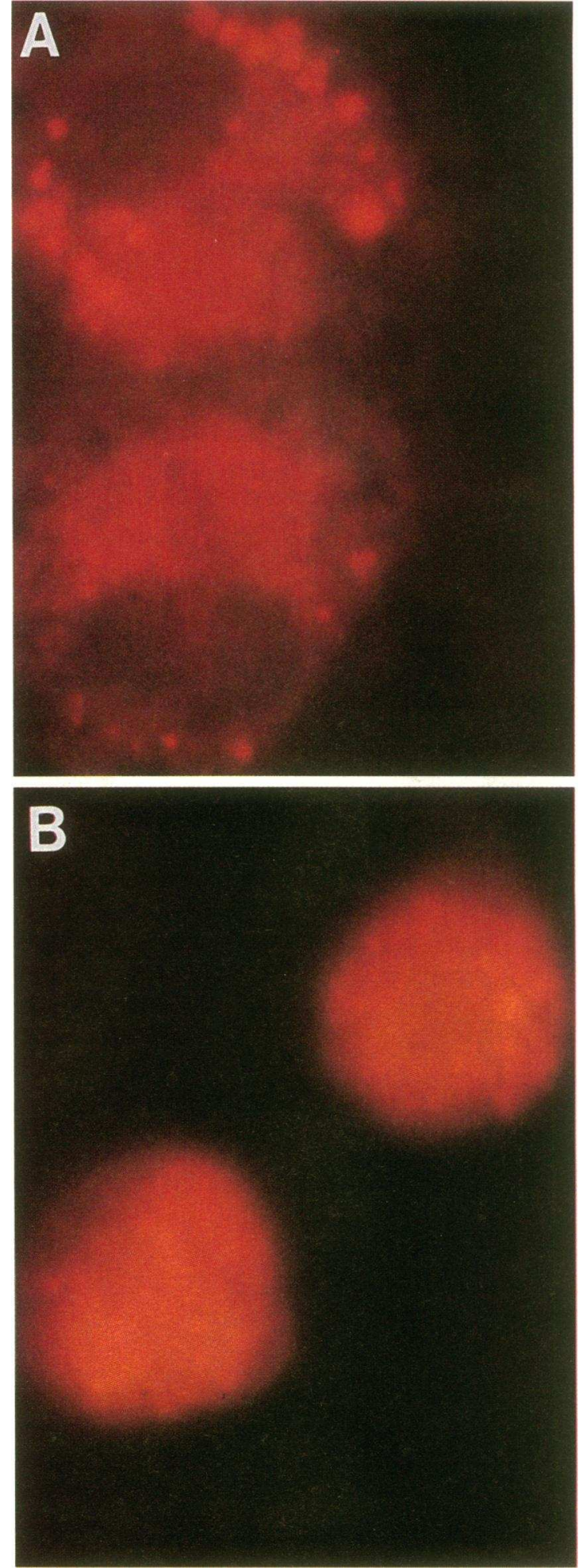

Figure 6. Representative examples of the association between NFkB nuclear expression and oxidative stress. NFkB was detected using NFkB65 and fluorescein-labeled second antibodies. NFkB immunofluorescence is shown for cells cultured on EHS matrix (control) $(A)$ and for $200 \mu \mathrm{M}$ malondialdehyde $(B) . \times 100$.

spanning either the c-myb site or the NFkB site (Fig. 9, lanes 6 and 7). Preimmune serum did not affect the protein-DNA complexes (not shown). As expected, the $\alpha$-SMA oligonucleo- 


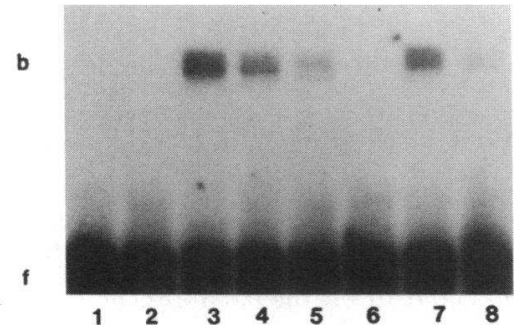
cleotide ( $1 \mathrm{ng}$ ). The DNA-protein complexes were resolved by electrophoresis on a $6 \%$ nondenaturing polyacrylamide gel. The positions of the free $(f)$ and bound $(b)$ DNA are indicated. Nuclear extracts on lanes 4 and 5 were preincubated with NFkB65 antibodies and monoclonal c-myb antibodies, respectively. Nuclear extracts on lanes 6,7 , and 8 were incubated with consensus oligonucleotides $(10 \mathrm{ng})$ for $\mathrm{NFkB}, \mathrm{c}-\mathrm{myb}$ and $\alpha$-SMA, respectively. Lane 1 was incubated without nuclear extracts.

tide competed the binding of nuclear extracts from activated stellate cells to the NFkB (Fig. 7, lane 8) and $\alpha$-SMA (Fig. 9, lane 8 ) oligonucleotides. These results strongly suggest a role for c-myb (and presumably NFkB) on a $\alpha$-SMA gene expression, a hallmark of stellate cell activation (25).

To ascertain whether these findings in culture stellate cells are relevant to the role of activated stellate cells in hepatic fibrosis, we studied the expression of c-myb in an animal model of liver fibrogenesis. Mice were treated with carbon tetrachloride, an hepatotoxin, that induces liver lipid peroxidation (15), malondialdehyde-protein adducts (10), stellate cell activation (25), collagen gene expression $(5,17)$, and in chronic treatments, liver cirrhosis $(5,33)$. Moreover, coculture experiments of hepatocytes and stellate cells treated with carbon tetrachloride, indicate that hepatocytes exert a paracrine stimulation of both lipid peroxidation and collagen gene expression on stellate

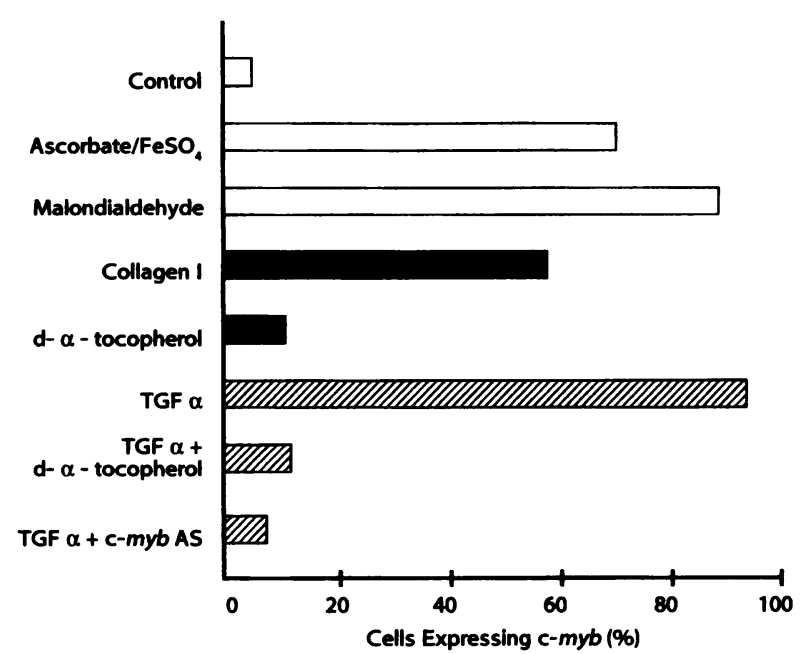

Figure 8. Oxidative stress induces c-myb expression in hepatic stellate cells. c-myb expression was detected by immunohistochemistry in primary stellate cells. Cells were cultured on EHS matrix (control, ascorbic acid [200 $\mu \mathrm{M}$ ] $/ \mathrm{FeSO}_{4}[50 \mu \mathrm{M}]$, and $200 \mu \mathrm{M}$ malondialdehyde), collagen type I matrix (collagen I and $50 \mu \mathrm{M} \mathrm{d}-\alpha$-tocopherol), or plastic ( $12 \mathrm{nM}$ TGF $\alpha$ alone or with the addition of either $50 \mu \mathrm{M} \mathrm{d}-\alpha$-tocopherol or $25 \mu \mathrm{M} \mathrm{c-myb}$ antisense [AS]), as described in Fig. 1. Values represent the percentage of cells positive for c-myb; $P<0.05$ for ascorbic acid $/ \mathrm{FeSO}_{4}$, malondialdehyde, and collagen I and TGF $\alpha$. The SEM was $<30 \%$ of the mean for all conditions.

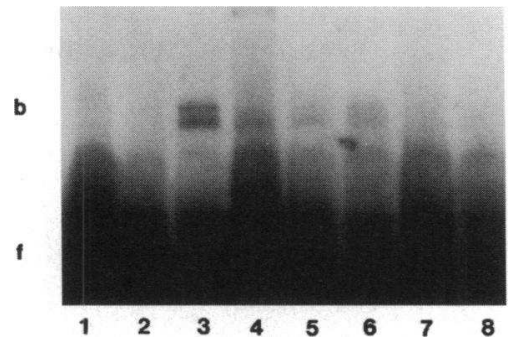

Figure 9. c-Myb is a major contributor to the $\alpha$ smooth muscle actin binding activities of activated stellate cells. Mobility shift analysis of nuclear extracts from quiescent (lane 2) and activated stellate cells (lanes 3-8) was per-

formed with samples incubated with ${ }^{32} \mathrm{P}$-labeled $\alpha$-SMA promoter Ebox ( $1 \mathrm{ng}$ ). The DNA-protein complexes were resolved as described in Fig. 7. Nuclear extracts on lanes 4 and 5 were preincubated with monoclonal c-myb antibodies and NFkB65 antibodies, respectively. Nuclear extracts on lanes 6,7 , and 8 were incubated with consensus oligonucleotides ( $10 \mathrm{ng}$ ) for NFkB, c-myb and $\alpha$-SMA, respectively. Lane $l$ was incubated without nuclear extracts.

cells (10). In this context, immunofluorescence studies established that c-myb expression (in yellow) was markedly increased in sinusoidal cells, with the phenotype of activated stellate cells, in liver sections of animals treated with carbon tetrachloride (Fig. $10 \mathrm{~B}$ ). Omission of the first antibody was associated with modest and diffuse background fluorescence. We found that c-myb expression is negligible in the liver of control animals treated with the vehicle mineral oil (Fig. $10 \mathrm{~A}$ ).

\section{Discussion}

Although overproduction of collagen type I by hepatic stellate cells is a critical step in the development of liver cirrhosis (16, $17,19,20)$, the regulation of collagen $\alpha_{1}(\mathrm{I})$ gene expression remains unclear ( 3 ). In this study, we have characterized some of the cellular pathways that are involved in the activation of quiescent stellate cells. Oxidative stress mediates the activation of stellate cells by collagen type I matrix or TGF $\alpha$. Moreover, we have identified a molecular mechanism leading to stellate cell activation.

Our results suggest a critical role of NFkB and c-myb on stellate cell activation given that during stellate cell activation the nuclear expression of NFkB and c-myb is increased, and that stellate cell activation, is blocked by antisense, but not by sense, c-myb. Also, we determined that in activated stellate cells, NFkB and c-myb contribute substantially to the nuclear binding activities to the promoter $\mathrm{E}$ box of the $\alpha$-SMA gene. These findings strongly suggest that NFkB and c-myb are the molecular mediators of oxidative stress on stellate cell activation, and that they bind to the critical E box of the $\alpha$-SMA gene (32), the expression of which is intrinsic to the activated phenotype of stellate cells (25). Relevant to this issue, coculture experiments of hepatocytes and stellate cells treated with carbon tetrachloride (a hepatocyte, but not a stellate cell, toxin), indicate that hepatocytes could exert a paracrine stimulation of both lipid peroxidation and collagen gene expression on stellate cells (10). Potential mediators of this model of oxidative stress in stellate cells include free radicals, reactive aldehydes or cytokines produced by the hepatocytes in response to carbon tetrachloride. In support of a role of reactive aldehydes on collagen gene expression, both acetaldehyde (6) and malondialdehyde (7), increase collagen $\alpha_{1}(\mathrm{I})$ gene transcription, and this effect can be blocked by scavengers of reducing equivalents (7) which are required for the formation of aldehyde-protein adducts. In 

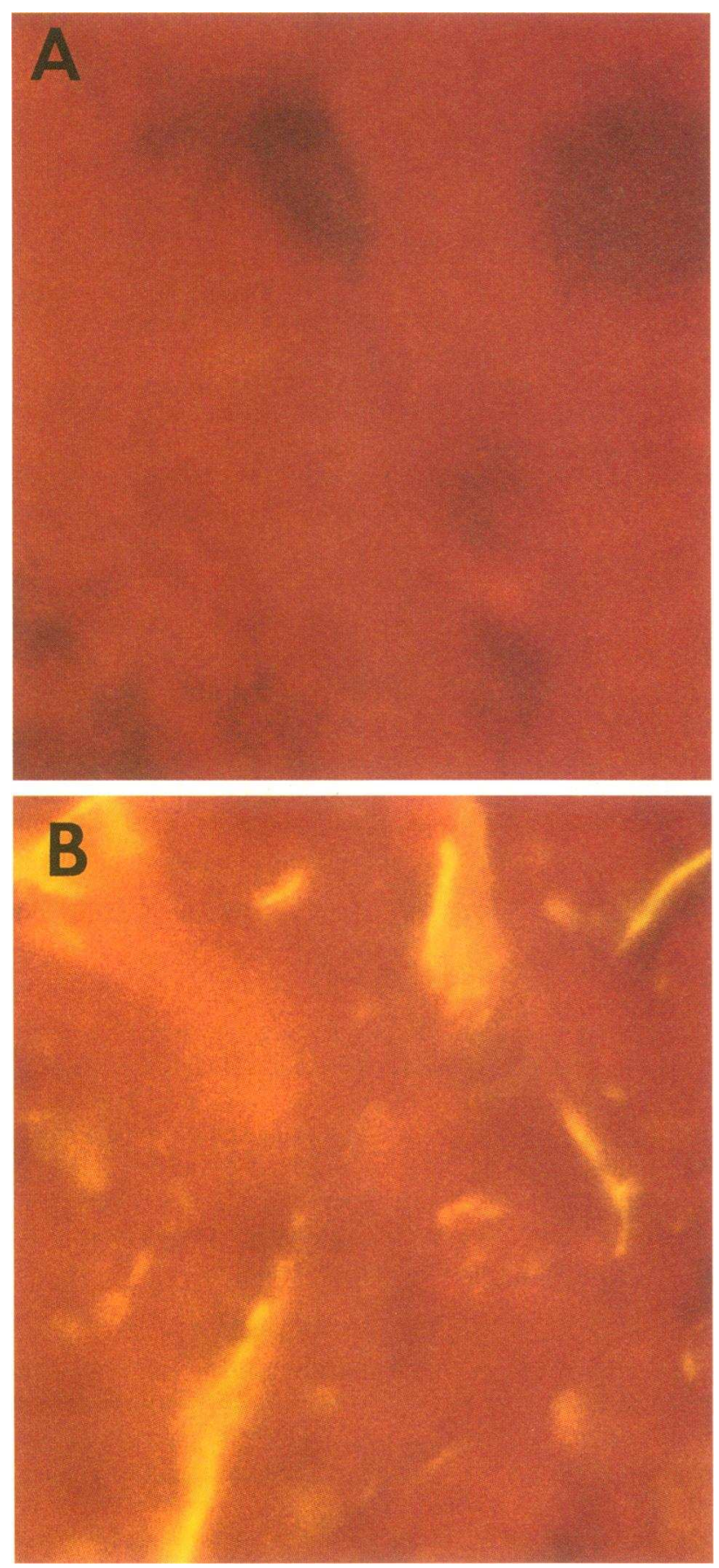

Figure 10. c-myb expression is increased in activated stellate cells in the liver following carbon tetrachloride-induced hepatic injury. c-myb expression (in yellow) was detected by immunofluorescence in liver sections using monclonal c-myb and fluorescein-labeled second antibodies, while Evans blue (in red) was used as counterstain. Liver sections were obtained from control $(A)$ and experimental $(B)$ mice, $48 \mathrm{~h}$ after the intraperitoneal injection of mineral oil vehicle or carbon tetrachloride in mineral oil, respectively. $\times 1,000$.

agreement with these findings, stellate cell collagen gene expression is stimulated by 4-hydroxynonenal, another product of lipid peroxidation (34).

In this context, we have demonstrated that malondialdehyde or the induction of lipid peroxidation, dramatically activates quiescent stellate cells. Moreover, antioxidants (such as d- $\alpha$ tocopherol or BHT) suppress the characteristic activation of stellate cells cultured on collagen type I matrix or TGF $\alpha$. Therefore, oxidative stress is both sufficient and indispensable for the activation of stellate cells.

Furthermore, activated stellate cells may also recruit nonactivated stellate cells by means of a paracrine mechanism, that has been suggested to perpetuate fibrogenesis (35). Several cytokines are known to facilitate activation of stellate cells, including PDGF, FGF, and TGF $\alpha$ (21). Interestingly, we have found evidence to support a convergence of lipid peroxidation and cytokine pathways in the activation of stellate cells. For example, the induction of stellate cell activation and proliferation by TGF $\alpha$ utilizes an oxidative pathway, because can be blocked with antioxidants. In addition, in iron overload in the absence of overt inflammation, lipid peroxidation induces the expression of TGF $\beta 1$ and collagen $\alpha_{1}$ (I) (11). Conversely, TGF $\beta 1$ exerts a prooxidant effect on cultured osteoblastic and endothelial cells $(36,37)$. TGF $\beta 1(38)$, lipid peroxidation and its aldehyde products (7), and acetaldehyde (6), a product of ethanol oxidation, which can induce lipid peroxidation (14), are known to stimulate collagen gene transcription. Acetaldehyde increases collagen synthesis in cultured human fibroblasts (39) and in activated stellate cells obtained from baboon liver (40). Also, acetaldehyde stimulates collagen production and mRNA expression in cultured rat stellate cells $(41,42)$.

Several studies indicate that c-myb plays an important role in cell differentiation and proliferation (for review see reference 43). For example, regulation of c-myb expression is critical for the growth and differentiation of the progeny of hematopoietic cells $(29,31,44)$. c-Myb protein binds to a consensus cognate DNA (45) through three homeo domain-like regions (46), and activates the transcription of target genes (47-49). These genes include the promyelocyte mim-1 (50), cdc2 (51) c-myc (52), and c-myb itself (53). A role for c-myb affecting the cell cycle before the $\mathrm{G} 1 / \mathrm{S}$ phase boundary, has been suggested $(54,55)$. Our results indicating that c-myb expression is important for proliferation of hepatic stellate cells supports its effect on cell entry into S-phase. Similarly, c-myb appears to be critical for the proliferation of vascular smooth muscle cells in culture (30) and in an animal model of arterial re-stenosis (56).

Although little is known about the mechanisms that modulate c-myb expression, it has been suggested that oxidation of Cys 43 could function as a molecular sensor for the redox state of the cell by affecting the DNA binding affinity of c-myb (57). The modulation of AP1 proteins involving reduction-oxidation is mediated by the nuclear redox factor Ref-1 (58), which also functions as a DNA repair enzyme (27). Ref-1 stimulates DNA binding activity of several transcription factors including c-myb, and may itself be under a posttranslational control which is sensitive to the redox state of the cell (27). The redox activity of Ref-1 is mediated through a conserved cysteine amino acid motif (KCR) that is present in Fos, c-Jun and related proteins. In c-myb, redox changes probably affects the motif KQCR (which includes Cys 43), within the DNA binding domain. In agreement with this novel hypothesis $(27,57)$, we found that oxidative stress affects the DNA binding activity and expression of c-myb. Although the molecular mechanisms remain to be elucidated, the increased expression of c-myb could be achieved for instance, by positive autoregulation of c-myb (53) through the oxyredox modulation of c-myb protein (27).

The precise molecular interactions of c-myb with other transcription factors is poorly understood. However, Ness et al. (59) have reported that c-myb and NF-M proteins act as a bipartite activator of myeloid-specific genes. In this context, we 
found that LAP(NF-IL6) (22), which is related to NF-M (60), is expressed in hepatic stellate cells (Houglum et al., unpublished observations). Moreover, LAP confers differentiated functions $(22,61-64)$ and blocks the cell cycle before the G1/ $\mathrm{S}$ boundary inhibiting the proliferation of hepatoma cells (23). Similarly, LAP is critical for adipocyte differentiation (65), a cell that resembles quiescent hepatic stellate cells in their ability to store fat $(19,65)$. Collectively, these results suggest the possibility that a LAP/c-myb interaction may occur in stellate cells, affecting the differentiation and/or proliferation of these cells. In addition, stellate cell differentiated functions could be modulated at least in part, by the interaction between LAP and NFkB (66), which is known to affect gene transcription (67). Our study provides insights into the molecular mechanisms leading to hepatic stellate cell activation, as well as a rationale for potential therapeutic approaches for hepatic fibrosis, a major contributor to the morbidity and mortality of patients with chronic liver diseases.

Note added in proof. A recent study by Burgess et al. (68) suggests that the antiproliferative activity of c-myb specific oligonucleotides, at least on smooth muscle cells, is not due to a hybridization-dependent antisense mechanism. Rather, a stretch of four contiguous guanosine residues, which is present in the antisense c-myb used by us (this publication) and others $(30,56)$, may be responsible for the sequence-specific but non-antisense antiproliferative effects of these oligonucleotides.

\section{Acknowledgments}

We are grateful to B. Stein (Signal Pharmaceuticals, San Diego, CA) and W. M. Kuehl (NCI-Naval Medical Oncology, Bethesda, MD) for providing the mammalian vectors expressing NFkB and c-myb, respectively. We thank C. Adams and A. Peña for the preparation of this manuscript.

This study was supported in part by the United States Public Health Service grants DK-38652, DK-46971, and GM-47165, and grants from the Department of Veterans Affairs, the American Liver Foundation, and the Ford Foundation. K. S. Lee was supported by a grant from Yonsei University College of Medicine (Seoul, S. Korea), and K. Houglum by a Clinical Investigator Award (DK-02265). This study is in partial fulfillment of M. Buck's Ph.D. degree in Biomedical Sciences Graduate Program.

\section{References}

1. Martinez-Hernandez, A. 1985. The hepatic extracellular matrix II. Electron immunohistochemical studies in rats with $\mathrm{CCl}_{4}$-induced cirrhosis. Lab. Invest 53:166-186.

2. Clément, B., J. A. Grimaud, J. P. Campion, Y. Deugnier, and A. Guillouzo. 1986. Cell types involved in collagen and fibronectin production in normal and fibrotic human liver. Hepatology. 6:225-234.

3. Chojkier, M. 1993. Pathogenesis of hepatic fibrosis. In Extracellular Matrix.

M. Zern, L. Reid, Editors/Marcel Dekker Inc., New York. 541-557.

4. Panduro, A., F. Shalaby, F. R. Weinter, L. Biempica, M. A. Zern, and D. A. Schafritz. 1986. Transcriptional switch from albumin to $\alpha$-fetoprotein and changes in transcription of other genes during carbon tetrachloride induced live regeneration. Biochemistry. 25:1414-1420.

5. Pierce, R. A., M. R. Glaug, and R. S. Greco. 1987. Increased procollagen mRNA levels in $\mathrm{CCl}_{4}$-induced liver fibrosis in rats. J. Biol. Chem. 262:1652 1658.

6. Brenner, D. A., and M. Chojkier. 1987. Acetaldehyde increases collagen gene transcription in cultured human fibroblasts. J. Biol. Chem. 262:1769017695 .

7. Chojkier, M., K. Houglum, J. Solis-Herruzo, and D. A. Brenner. 1989. Stimulation of collagen gene expression by ascorbic acid in cultured human fibroblasts. J. Biol. Chem. 264:16957-16962.

8. Houglum, K., D. A. Brenner, and M. Chojkier. 1991. Inhibition of collagen gene expression by $\mathrm{d}-\alpha$-tocopherol in cultured human fibroblasts. J. Clin. Invest. 87:2230-2235.

9. Houglum, K., M. Filip, J. L. Witztum, and M. Chojkier. 1990. Malondialde- hyde and 4-hydroxynonenal protein adducts in plasma and liver of rats with iron overload. J. Clin. Invest. 86:1991-1998.

10. Bedossa, P., K. Houglum, C. Trautwein, A. Holstege, and M. Chojkier. 1994. Stimulation of collagen $\alpha_{1}$ (I) gene expression is associated with lipid peroxidation in hepatocellular injury. A link to tissue fibrosis? Hepatology. 19:1262-1271.

11. Houglum, K., P. Bedossa, and M. Chojkier. 1994. TGF $\beta$ and collagen $\alpha_{1}(\mathrm{I})$ gene expression are increased in hepatic acinar zone 1 of rats with iron overload. Am. J. Physiol. 267:G908-G913.

12. Bacon, B. R., A. T. Tavill, G. M. Brittenham, C. H. Park, and R. O. Recknagel. 1983. Hepatic lipid peroxidation in vivo in rats with chronic iron overload. J. Clin. Invest. 71:429-439.

13. Poh-Fitzpatrick, M. B. 1982. Pathogenesis and treatment of photocutaneous manifestations of the porphyrias. Semin. Liv. Dis. 2:164-176.

14. Schauenstein, E. H., H. Esterbauer, and H. Zollner. 1977. Aldehydes in biological systems. Pion Limited, London. 1-102.

15. Burk, R. F., J. M. Lane, and K. Patel. 1984. Relationship of oxygen and glutathione in protection against carbon tetrachloride-induced hepatic microsomal lipid peroxidation and covalent binding in the rat. J. Clin. Invest. 74:1996-2001.

16. Friedman, S., F. Roll, J. Boyles, and D. Bissell. 1985. Hepatic stellate cells: the principal collagen-producing cells of the liver. Proc. Natl. Acad. Sci. USA. 82:8681-8685.

17. Maher, J. J., and R. F. McGuire. 1990. Extracellular matrix gene expression increases preferentially in rat stellate cells and sinusoidal endothelial cells during hepatic fibrosis in vivo. J. Clin. Invest. 86:1641-1648.

18. Brenner, D. A., J. M. Alcorn, H. L. Leffert, S. P. Feitelberg, and M. Chojkier. 1990. Expression of collagen genes in the liver. Mol. Biol. Med. 7:105115.

19. Davis, B. H., B. M. Pratt, and J. A. Madri. 1987. Retinol and extracellular collagen matrices modulate hepatic Ito cell collagen phenotye and cellular retinol binding protein levels. J. Biol. Chem. 262:10280-10286.

20. Friedman, S. L., F. J. Roll, J. Boyles, D. M. Arenson, and D. M. Bissell. 1989. Maintenance of differentiated phenotype of cultured rat hepatic stellate cells by basement membrane matrix. J. Biol. Chem. 264:10756-10762

21. Pinzani, M., L. Gesulado, G. Sabbah, and H. Abboud. 1989. Effects of platelet derived growth factor and other polypeptide mitogens on DNA synthesis and growth of cultured rat liver fat storing cells. J. Clin. Invest. 84:1786-1793.

22. Descombes, P., M. Chojkier, S. Lichtsteiner, E. Falvey, and U. Schibler. 1990. LAP, a novel member of the C/EBP gene family, encodes a liver-enriched transcriptional activator protein. Genes \& Dev. 4:1541-1551.

23. Buck, M., H. Turler, and M. Chojkier. 1994. LAP, a tissue-specific transcriptional activator, is an inhibitor of hepatoma cell proliferation. EMBO (Eur Mol. Biol. Organ.) J. 13:851-860.

24. Trautwein, C., P. van der Geer, M. Karin, T. Hunter, and M. Chojkier. 1994. Protein kinase A and C site-specific phosphorylations of LAP (NF-IL6) modulate its binding affinity to DNA-recognition elements. J. Clin. Invest 93:2554-2561

25. Rockey, D., J. Boyles, G. Gabbiani, and S. Friedman. 1992. Rat hepatic stellate cells express smooth muscle actin upon activation in vivo and in culture. J. Submicrosc. Cytol. 24:193-203.

26. Bravo, R., R. Frank, P. A. Blundell, and H. MacDonald-Bravo. 1987. Cyclin/PCNA is the auxiliary protein of DNA polymerase-delta. Nature (Lond.) 326:515-517.

27. Xanthoudakis, S., G. Miao, F. Wang, Y. C. E. Pan, and T. Curran. 1992 Redox activation of Fos-Jun DNA binding activity is mediated by a DNA repair enzyme. EMBO (Eur. Mol. Biol. Organ.) J. 11:3323-3335.

28. Henkel, T., T. Machleidt, I. Alkalay, M. Kronke, Y. Ben-Neriah, and P. Baeuerle. 1993. Rapid proteolysis of IkB- $\alpha$ is necessary for activation of transcription factor NF-kB. Nature (Lond.). 365:182-185.

29. Thompson, C., P. Challoner, P. Neiman, and M. Groudine. 1986. Expression of the c-myb proto-oncogene during cellular proliferation. Nature (Lond.). 319:374-380.

30. Simons, M., and R. D. Rosenberg. 1992. Antisense nonmuscle myosin heavy chain and c-myb oligonucleotides suppress smooth muscle cell proliferation in vitro. Circ. Res. 70:835-843.

31. Badiani, P., P. Corbella, D. Kioussis, J. Marvel, and K. Weston. 1994 Dominant interfering alleles define a role for $\mathrm{c}-\mathrm{Myb}$ in $\mathrm{T}$-cell development. Genes \& Dev. 8:770-782.

32. Blank, R. S., T. C. McQuinn, K. C. Yin, M. M. Thompson, K. Takeyasu R. J. Schwartz, and G. K. Owens. 1992. Elements of the smooth muscle $\alpha$-actin promoter required in cis for transcriptional activation in smooth muscle. J. Biol. Chem. 267:984-988.

33. Chojkier, M., and R. J. Groszmann. 1981. A method to measure portalsystemic shunting in rats by using gamma-labeled microspheres. Am. J. Physiol. 240:G371-G375.

34. Parole, M., M. Pinzani, A. Casini, E. Albano, G. Poli, A. Gentilini, P. Gentilini, and M. U. Dianzani. 1993. Stimulation of lipid peroxidation or 4 hydroxynonenal treatment increases procollagen alpha 1 (I) gene expression in human liver fat-storing cells. Biochem. Biophys. Res. Commun. 194:1044-1050.

35. Bachem, M. G., D. Meyer, R. Melchior, K.-M. Sell, and A. M. Gressner 
1992. Activation of rat liver perisinusoidal stellate cells by transforming growth factors derived from myofibroblastlike cells. J. Clin. Invest. 89:19-27.

36. Shibanuma, M., T. Kuroki, and K. Nose. 1991. Release of $\mathrm{H}_{2} \mathrm{O}_{2}$ and phosphorylation of 30 kiladalton proteins as early responses of cell cycle-dependent inhibition of DNA synthesis by transforming growth factor $\beta_{1}$. Cell Growth \& Differ. 2:583-591.

37. Das, S. K., and B. L. Fanburg. 1991. TGF- $\beta$ produces a "prooxidant" effect on bovine pulmonary artery endothelial cells in culture. Am. J. Physiol. 261:L249-L254.

38. Rossi, P., G. Garsenty, A. B. Roberts, N. S. Roche, M. B. Sporn, and B. de Crombrugghe. 1988. A nuclear factor I binding site mediates the transcriptional activation of type I collagen promoter by transforming growth factor $\beta$. Cell. 52:405-414.

39. Holt, K., M. Bennett, and M. Chojkier. 1984. Acetaldehyde stimulates collagen and noncollagen protein production by human fibroblasts. Hepatology. 4:843-848.

40. Savolainen, E.-R., M. A. Leo, R. Timpl, and C. S. Lieber. 1984. Acetaldehyde and lactate stimulate collagen synthesis of cultured baboon liver myofibroblasts. Gastroenterology. 87:777-787.

41. Moshage, H., A. Casini, and C. S. Lieber. 1990. Acetaldehyde selectively stimulates collagen production in cultured rat liver fat-storing cells but not in hepatocytes. Hepatology. 2:511-518.

42. Casini, A., M. Cunningham, M. Rojkind, and C. S. Lieber. 1991. Acetaldehyde increases procollagen type I and fibronectin gene transcription in cultured rat fat-storing cells through a protein synthesis-dependent mechanism. Hepatology. 13:758-765.

43. Lüscher, B., and R. N. Eisenman. 1990. New light on Myc and Myb. Part II. Myb. Genes \& Dev. 4:2235-2241.

44. Gewirtz, A. M., and B. Calabretta. 1988. A c-myb antisense oligodeoxynucleotide inhibits normal human hematopoiesis. Science (Wash. DC). 242:1303 1306.

45. Gabrielsen, O. S., A. Sentenac, and P. Fromageot. 1991. Specific DNA binding by c-Myb: evidence for a double helix-turn-helix-related motif. Science (Wash. DC). 253:1140-1143.

46. Saikumar, P., R. Murali, and E. P. Reddy. 1990. Role of tryptophan repeats and flanking amino acids in Myb-DNA interactions. Proc. Natl. Acad. Sci. USA. $81: 8452-8456$

47. Klempnauer, K.-H., G. Symonds, G. I. Evans, and J. M. Bishop. 1984. Subcellular localization of proteins encoded by oncogenes of avian myeloblastosis virus and avian leukemia virus E26 and by chicken c-myb gene. Cell. 37:537547.

48. Weston, K., and J. M. Bishop. 1989. Transcriptional activation by the vmyb oncogene and its cellular progenitor, c-myb. Cell. 58:85-93.

49. Biedenkapp, H., U. Borgmeyer, A. E. Sippel, and K. H. Klempnauter 1988. Viral myb oncogene encodes a sequence-specific DNA-binding activity. Nature (Lond.). 335:835-837.

50. Ness, S. A., A. Marknell, and T. Graf. 1989. The v-myb oncogene product binds to and activates the promyelocyte-specific mim-1 gene. Cell. 59:11151125

51. Ku, D. H., S. C. Wen, A. Engelhard, N. C. Nicolaides, K. E. Lipton, T. A Marino, and B. Calabretta. 1993. c-myb transactivates $c d c 2$ expression via Myb binding sites in the 5 '-flanking region of the human $c d c 2$ gene. J. Biol. Chem. 268:2255-2259.

52. Evans, J. L., T. L. Moore, W. M. Kuehl, T. Bender, and J. P. Ting. 1990.
Functional analysis of c-Myb protein in T-limphocytic cell lines shows that it trans-activates the c-myc promoter. Mol. Cell. Biol. 10:5747-5752.

53. Nicolaides, N. C., R. Gualdi, C. Casadevall, L. Manzella, and B. Calabretta. 1991. Positive autoregulation of c-myb expression via Myb binding sites in the 5' flanking region of the human c-myb gene. Mol. Cell. Biol. 11:61666176.

54. Furukawa, Y., H. Piwnica-Worms, T. J. Ernst, Y. Kanakura, and J. D. Griffin. 1990. $c d c 2$ gene expression at the $\mathrm{G}_{1}$ to $\mathrm{S}$ transition in human $\mathrm{T}$ lymphocytes. Science (Wash. DC). 250:805-808.

55. Travali, S., K. Reiss, A. Ferber, S. Petralia, W. E. Mercer, B. Calabretta and R. Baserga. 1991. Constutively expressed c-myb abrogates the requirement for insulinlike growth factor 1 in 3T3 fibroblasts. Mol. Cell. Biol. 11:731-736.

56. Simons, M., E. R. Edelman, J. L. DeKeyser, R. Langer, and R. D. Rosenberg. 1992. Antisense c-myb oligonucleotides inhibit intimal arterial smooth muscle cell accumulation in vivo. Nature (Lond.). 359:67-70.

57. Myrset, A. H., A. Bostad, N. Jamin, P. N. Lirsac, F. Toma, and O. S. Gabrielsen. 1993. DNA and redox state induced conformational changes in the DNA-binding domain of the Myb oncoprotein. EMBO (Eur. Mol. Biol. Organ.) J. 12:4625-4633.

58. Xanthoudakis, S., and T. Curran. 1992. Identification and characterization of Ref-1, a nuclear protein that facilitates AP-1 DNA-binding activity. EMBO (Eur. Mol. Biol. Organ.) J. 11:653-665.

59. Ness, S. A., E. Kowenz-Leutz, T. Casini, T. Graf, and A. Leutz. 1993. Myb and NF-M: combinatorial activators of myeloid genes in heterologous cell types. Genes \& Dev. 7:749-759.

60. Katz, S., E. Kowenz-Leutz, C. Müller, K. Meese, S. A. Ness, and A. Leutz. 1993. The NF-M transcription factor is related to C/EBP $\beta$ and plays a role in signal transduction, differentiation and leukemogenesis of avian myelomonocytic cells. EMBO (Eur. Mol. Biol. Organ.) J. 12:1321-1332.

61. Akira, S., H. Isshiki, T. Sugita, O. Tanabe, S. Kinoshita, Y. Nishio, T. H. Nakajima, and T. Kishimoto. 1990. A nuclear factor for IL-6 expression (NFIL6) is a member of a C/EBP family. EMBO (Eur. Mol. Biol. Organ.) J. 9:18971906.

62. Poli, V., F. P. Mancini, and R. Cortese. 1990. IL-6DBP, a nuclear protein involved in interleukin- 6 signal transduction, defines a new family of leucine zipper proteins related to C/EBP. Cell. 63:643-653.

63. Trautwein, C., C. Caelles, P. van der Geer, T. Hunter, M. Karin, and M. Chojkier. 1993. Transactivation by NF-IL6/LAP is enhanced by phosphorylation of its activation domain. Nature (Lond.). 364:544-547.

64. Houglum, K., M. Buck, V. Adir, and M. Chojkier. 1994. LAP (NF-IL6) transactivates the collagen $\alpha_{1}(\mathrm{I})$ gene from a 5' regulatory region. J. Clin. Invest. 94:808-814.

65. Cao, Z., R. M. Umek, and S. L. McKnight. 1991. Regulated expression of three C/EBP isoforms during adipose conversion of 3T3-L1 cells. Genes \& Dev. 5:1538-1552.

66. Stein, B., P. Cogswell, and A. Baldwin. 1993. Functional and physical associations between NF-kB and C/EBP family members: rel domain-bZIP interaction. Mol. Cell. Biol. 13:3964-3974.

67. Stein, B., and A. Baldwin. 1993. Distinct mechanisms for regulation of the interleukin- 8 gene involve synergism and cooperativity between C/EBP and NF-kB. Mol. Cell. Biol. 13:7191-7198.

68. Burgess, T. L., E. F. Fisher, S. L. Ross, J. V. Bready, Y.-X. Qian, L. A. Bayewitch, A. M. Cohen, C. J. Herrera, S. S.-F. Hu, T. B. Kramer, et al. 1995. The antiproliferative activity of c-myb and c-myc antisense oligonucleotides in smooth muscle cells is caused by a nonantisense mechanism. Proc. Natl. Acad. Sci. USA. 92:4051-4055. 